інстинктів і стійких комплексів похідних почуттів; оптимізації подальшого продукування відповідних гіпотетичних конструктів, термінологічних визначень і математичних образів для вербального і графічного міждисциплінарного опису досліджуваних когнітивістами феноменів.

Ключові слова: інстинкти, емоції, почуття, мегакласифікація, міждисциплінарні дослідження.

Klymenyuk Aleksandr. Instincts, Emotions and Feelings: an Interdisciplinary Lingual-and-Psychological Mega-Classification. The paper presents a substantiation of a hypothetical mega-classification of instincts, emotions and feelings. The classification has been worked out by applying the content based semantic analysis of centuries-old interdisciplinary lingual-and-psychological knowledge on the basis of the author's orthodox-and-alternative approach, the orthodox element being represented by the energy of human instincts, while the alternative elements signify the feelings experienced by the individual. The methodology for modeling an interdisciplinary mega-classification is based on the idea of organic synthesis of related conceptual views of philosophy, cognitive science, a systemic approach, synergetics and cybernetics. The logical procedure of structuring the conceptual elements of mega-classification comprises the following: (1) the hierarchy of elements along the vector of psycho-physiological energy movement according to the sequence of acts of origin and self-development of the individual's speaking-and-thinking cognitive activities viewed as a single uninterrupted synergetic process; (2) the location of the multitude of elements in the morphological rows of each hierarchical level according to the vector (or criterion) of their energetic (or emotional-and-pragmatic) potential is in the direction from larger elements to smaller ones; (3) direct and reverse links between the elements of all the levels of classification being viewed as an open cybernetic system. The paper shows the multifunctional potential of mega-classification as a universal methodological tool for the interdisciplinary cognitive study that allows the researcher to use it as a reliable instrument for a number of scientific procedures. Such procedures include: conventionalization of the interdisciplinary notions and terms of cognitive sciences; effective formation of working classifications within the scope of each specific cognitive search, which, as is known, performs the role of methodological grounds in the development of any experimental research program and methodology; the substantiation of an integrated strategy and system of the unified tactics for conducting statistical cognitive mega-experiments. The scientific potential of mega-classification also lies in the creation of a computerized data basis of the results of studying instincts, emotions and feelings, being indexed according to their mega-classification as well as in the quantitative evaluation of statistical regularities of the individuals' psycho-physiological energies circulation in typical communicative situations. The mega-classification can serve as a basis for finding out the norms of quantitative indicators, or energetic thresholds of psychophysiological energy characteristics of various types of the individual's cognitive activities, considering that the excess of this energy leads to the fixation of the acquired instincts and stable complexes of the derived feelings in human's memory. The multifunctional potential of the offered mega-classification can be realized in systemic planning and carrying out of the subsequent interdisciplinary cognitive scientific research of the objects of any area of the existing boundless object-sphere comprising psycho-, socio-, and physiological phenomena as well as in the optimization of further generation of corresponding hypothetical constructs, terminological definitions and mathematical images for a verbal and graphical interdisciplinary description of the phenomena studied by cognitive scientists.

Keywords: instincts, emotions, feelings, mega-classification, interdisciplinary research.

DOI: https://doi.org/10.32782/2410-0927-2020-12-19

УДК 81’23:159.937.523

Еліна Коляда, Тетяна Лісінська

\title{
БАЗОВІ ПОНЯТТЯ СЕНСОРНОЇ ЛІНГВІСТИКИ
}

У статті розглянуто ключові поняття сенсорної лінгвістики, яка вивчає систему мовних репрезентацій фізіологічних показників п'яти органів чуття - зору, слуху, нюху, смаку і дотику. Відчуття відображають властивості предметів і явищ навколишнього світу. За обсягом сприйнятої інформації в ієрархії п'яти сенсорних підсистем людини перше місце посідає зір, друге - слух. Реєстратором результатів сприймання є перцептивні мовні засоби, де лексичний рівень найбільш значимий. Нерівноцінність перцептивних відчуттів, як і різна кількість мовних знаків їх вираження, знаходить своє відображення в словниковому складі мови.

Вербалізатори чуттєвого сприймання в мовній системі морфологічно представлені різними частинами мови: іменниками, прикметниками, дієсловами, прислівниками, оскільки всім повнозначним словам притаманна номінативна функція. 3 огляду на категорійне значення в іменнику сенсорна ознака $є$ опредметненою; прикметник виражає сенсорну ознаку як статичну, невіддільну від предмета; дієслово виражає динамічну сенсорну ознаку; у прислівнику сенсорна ознака - це ознака іншої (процесуальної чи статичної) ознаки.

Інтерес науковців до результатів мовної об'єктивації чуттєвого сприймання породжує перцептивність як лінгвістичну категорію. Базовим для сенсорної лінгвістики є поняття “сенсорний”, що використовується нарівні 3 поняттям “перцептивний”. Однак в англомовній традиції “сенсорний” співвідноситься з відчуттям, а “перцептивний” - зі сприйманням.

(С) Коляда Е., Лісінська Т., 2020 
Для називання окремого виду відчуття лінгвісти використовують термін “перцептивний модус". Для позначення назв відчуттів слугують терміни латинського походження: “візуальний”, “аудіальний”, “тактильний” (“гаптичний”), “ольфакторний”, “густативний”.

Ключовим для праць із сенсорики є поняття “сенсорний досвід”. Саму людину, що зазнає відчуття, називають периептором, перцииіснтом або експериєнцером. Терміни перцептор і перцииієнт співвідносяться 3 актуальним, наявним сенсорним досвідом, який здобувається “тут і зараз”, а експериєнцер - із сукупним сенсорним досвідом, акумульованим упродовж життя людини.

Ключові слова: сенсорна лінгвістика, перцептивність, перцептивний модус, сенсорна лексика, частина мови.

Вступ. У лінгвістиці останніх десятиліть спостережено відгалуження такого напряму, як сенсорна лінгвістика (лінгвосенсорика, лінгвістична перцептологія (від лат. perception сприймання)), що вивчає систему мовних репрезентацій фізіологічних показників п'яти органів чуття $[14$, с. 6$]$. Формування сенсорної лінгвістики як міждисциплінарного наукового напряму обумовлено сучасними тенденціями в розвитку гуманітарного знання в цілому і лінгвістики зокрема $[20$, с. 4]. У фокус уваги сучасних зарубіжних і вітчизняних лінгвістів потрапляють способи сприймання людиною навколишньої дійсності, особливості відображення в людській свідомості тих предметів і явищ, які діють у певний момент на органи чуття $[4 ; 5 ; 26 ; 33]$.

Основна мета статті полягає в теоретичному узагальненні основних положень сенсорної лінгвістики. Завдання статті передбачають висвітлення базових понять зазначеного напряму сучасного мовознавства та їх інтерпретацію.

Методи та методики дослідження. Для досягнення поставленої мети використано такі методи, як узагальнення, порівняння та синтез.

Результати та дискусії. Мова слугує “вікном у світ відчуттів” [18, с. 7]. Ми пізнаємо навколишній світ завдяки органам чуття, що є єдиними каналами, через які зовнішній світ проникає в людську свідомість. Людина має п'ять органів чуття: зір, слух, нюх, смак і дотик. Залежно від того, як відбувається подразнення, органи чугтя поділяють на: 1) контактні (смаковий і дотиковий), збудження в яких виникають при безпосередньому контакті 3 подразником; 2) дистантні (зоровий, слуховий, нюховий), коли подразник знаходиться на певній відстані [23, с. 234]. Відчуття відображають властивості предметів і явищ матеріального світу. Приблизно 90\% інформації про світ людина отримує за допомогою зорових відчуттів. До зорових відчуттів належать відчуття світла і кольору. Всі відчуття кольору характеризуються тоном і яскравістю. Зір завжди вважали “благородним” відчуттям і асоціювали його з духовним просвітленням й інтелектуальною освіченістю [12, с. 1]. Зір став “служницею раціоналістичної науки" [28, с. 23], оскільки він є основним джерелом інформації для людини і надійним способом ії верифікації. Зір вважають найменш суб'єктивним 3 усіх відчуттів і найбільш підходящим перцептивним модусом для наукових досліджень $[11$, с.6], а можливість безпосереднього спостереження стала критерієм істинності.

Відмінність слухового сприймання від інших видів перцепції полягає в тому, що аудильний об'єкт активний і самодостатній для сприймання, тоді, як наприклад, зоровий образ являє собою сукупність якостей об'єкта і джерела світла, тобто переважна більшість об'єктів зорового сприймання (за винятком джерел світла) пасивні й несамодостатні [27, с. 183]. За обсягом сприйнятої інформації в ієрархії п'яти сенсорних підсистем людини слух поступається тільки зору [27, с. 182]. Слухові відчуття дають знання про звуки, які різняться за 1) висотою; 2) гучністю і 3) тембром [23, с. 65]. Джерелами звуку є як природне середовище (шелест листя, шум вітру, рев водоспаду, вокалізації тварин тощо), так і продукти матеріальної та духовної культури людини (транспорт, прилади, механізми, мовлення, музика і т. п.). Починаючи з часів промислової революції, звуки природи активно витісняються з акустичного середовища західної людини звуками техногенними, особливо у великих містах. В англомовній традиції слуховий модус сприймання, за спостереженнями Б. Джонсона, значною мірою дискредитований як джерело інформації. Достовірності зору (Seeing is believing - Побачити - значить повірити) протистоїть ненадійність, оманливість слуху (Do not believe everything you hear - He вip всьомy, щзо чуєш). Багато слів, що позначають передачу інформації слуховим каналом, в XVII-XVIII ст. отримали негативні конотації: “hearsay" (плітки, спочатку “почути сказане" - "hear say"); “gossip” (пліткар, спочатку “друг-співрозмовник”) [13]. 
Нюх забезпечує відчуття $\mathrm{i}$ розрізнення пахучих речовин. Найпоширенішою $\epsilon$ класифікація, за якою виокремлюють чотири основні запахи: ароматний, кислий, горілий i гнилісний [23, с. 64]. Запах, на відміну від кольору або звуку, не сприймається як самостійна сутність, у відриві від його носія. Невідчужуваність запаху від джерела змушує людину вдаватися до “запахової референції": the smell of fresh paint/earth/oranges (заnax cвiжcoi фарби/землі/апельсинів) [20, с. 49]. Як пише Дж. Дробнік, запахи - це неперевершені каталізатори спогадів про давно минулі події і віддалені місця [6, с. 1]. Ця здатність пов'язана 3 тим, що запахи, значна частина яких сприймається на сублімінальному рівні, мають виражений “афективний вимір” [10, с. 16], впливаючи на нашу емоційну сферу. Цінність нюху як способу пізнання визнається наївною свідомістю сучасної західної людини, що знаходить відображення в таких висловах, як I smelt a rat (я передчував щзось недобре), I smell trouble (я відчуваю неприємності).

Смакові відчуття поділяють на гіркі, кислі, солодкі і солоні. Інші смаки виникають у результаті змішування основних смаків [23, с. 65]. Смак так само значимий для людини, як щастя чи надія, оскільки він причетний не просто до пізнання, а до самого буття, до самого існування "Я" [16, с. 49], смакові відчуття впливають на людину сильніше, ніж запахи, і визначають іiі стан більше, ніж звуки, оскільки необхідність у харчуванні робить для людини смак більш важливим [15, с. 234]. Як пише В. фон Хоффманн, відчуття смаку здається надто суб'єктивним, щоб допускати узагальнення; воно настільки миттєве, що передує думці та мові $[9$, c. 14].

Дотик - вид людського сприймання, в якому при формуванні образу предмета основну роль відіграють тактильні відчуття, що виникають під час дії механічних подразників на поверхню шкіри і відображають об'єктивні властивості предметів: твердість, м'якість, рівність поверхні, сухість, вологість, шершавість тощо [23, с. 66]. На думку М. М. Бахтіна, дотик $\epsilon$ найбільш тілесним з усіх видів відчуттів і дозволяє осягати буття як таке. Він пише про особливу “мудрість дотику", віддаючи йому пріоритет перед зором і слухом. Зір і слух вимагають деякої віддаленості від предмета сприймання і підкреслюють нашу “відчуженість, відірваність” від навколишнього світу. Лише дотик здатний "реально долучити нас до речей”, оскільки він зберіг “свою невинну цілісність і чистоту". Зір і слух - це "нездійсненна можливість", це "можливий підступ до оволодіння предметом". Дотик $є$ найдавніше, найправдивіше, найбільш земне 3 наших чуттів, що дозволяє нам повною мірою пізнати предмет [3, с. 36].

Сприймання у мовознавстві породжує перцептивність як лінгвістичну категорію [27, c. 113]. Для позначення окремого виду відчуття в лінгвістиці використовується термін "перцептивний модус" або "модус перцепції" [24], який практично повністю витіснив у сучасних працях термін "модус чуттєвого сприймання" [2]. Термінологічне визначення окремих модусів виявляє широку варіативність. Використовуються як традиційні назви відчуттів (напр., “перцептивний модус 'запах"” [4]), так і їхні ад’єктивні деривати (напр., “зоровий модус" [8]), а також терміни латинського походження: "візуальний” ("visual" - зоровий), "аудіальний" (“audial” - слуховий), “тактильний” (“tactile” - дотиковий) або "гаптичний” ("haptic"), “ольфакторний” (“olfactory” - запаховий) [5], “густативний” (“gustatory” - смаковий).

Названі модуси сприймання - це найбільш елементарні форми відображення дійсності, процеси, через посередництво яких людина відтворює окремі ознаки зовнішнього світу. Однак реальні процеси відображення зовнішнього світу виходять далеко за межі елементарних форм. Людина живе у світі складних ситуацій, сприймаючи які, вона послуговується не окремими ізольованими відчуттями, а цілими образами, відображення яких грунтується на співпраці органів чуття, синтезі окремих відчуттів у складні комплексні системи. Тобто ми перетворюємо розрізнені відчуття в цілісне сприймання, переходимо від відображення окремих ознак до відтворення цілих предметів чи ситуацій [17, с. 124].

Ключовим для багатьох праць із сенсорики є поняття “сенсорний досвід”, під яким може розумітися як короткочасне, дискретне чуттєве враження, так і сукупний досвід переживання різноманітних відчуттів, який людина набуває упродовж життя. Саму людину, що зазнає відчуття, зазвичай називають периептором [31]. Необхідно зазначити, що за перцептором 
традиційно закріплений переважно візуальний модус сприймання, і цей термін трапляється в основному в працях, присвячених дослідженню категорії “спостерігач”, яка номінується, як правило, трьома можливими лексичними способами - спостерігач, суб'єкт сприймання, периептор при повній взаємозамінності перцептора і суб'єкта сприймання як термінів єдиної смислової природи, але різного мовного походження [там само, с. 22].

Зрозуміло, що “спостерігач” є парасольковим поняттям, яке охоплює всі перцептивні модуси і позначає ситуацію безпосереднього залучення в описувану подію. Однак з огляду на його усталене вживання і семантичну близькість 3 поняттям “суб'єкт” деякі дослідники вважають за доцільне використовувати в сенсорній лінгвістиці термін периипієнт [19, с. 57], який широко використовується в зарубіжних працях із тілесної і сенсорної проблематики (див., наприклад: [30]).

О. В. Нагорна пропонує доповнити терміносистему сенсорної лінгвістики одиницею експериєнцер. У цьому випадку периептор/периипієнт співвідноситься з актуальним, наявним сенсорним досвідом, який здобувається “тут і зараз”, а експериєнщер - із сукупним сенсорним досвідом, акумульованим упродовж життя людини [19, с. 57]. Це розмежування релевантне 3 погляду лінгвокогнітивної перспективи, оскільки когнітивні механізми, задіяні в ретроспективному описі відчуття, дещо відрізняються від тих, які використовуються безпосередньо в момент переживання досвіду [там само, с. 57].

Чуттєве сприймання, що корелює з мисленням, трансформується у факт свідомості й далі вербалізується. Вербалізатори чуттєвого сприймання в мовній системі морфологічно представлені різними частинами мови: іменниками, прикметниками, дієсловами, прислівниками, оскільки всім словам притаманна номінативна функція [32, с. 34]. 3 огляду на категорійне значення в іменнику сенсорна ознака є опредметненою; прикметник виражає сенсорну ознаку як статичну, невіддільну від предмета; дієслово виражає динамічну сенсорну ознаку; у прислівнику сенсорна ознака - це ознака іншої (процесуальної чи статичної) ознаки [27, с. 121]. Сенсорні лексеми являють собою сплав двох сигнальних систем (сприймання та обробки даних); у них закодована вся інформація про навколишній світ; вони виконують роль регістратора результатів сприймання [26, с. 466]. За кожною одиницею сенсорної лексики стоїть чуттєвий образ здатність передавати в конкретно-чуттєвій формі складний зміст.

Базовим для сенсорної лінгвістики є поняття “сенсорний”, що використовується нарівні 3 поняттям “перцептивний”. В англомовній традиції “сенсорний” співвідноситься 3 відчугтям, а "перцептивний" - зі сприйманням, позначаючи, таким чином, різні з психологічної точки зору явища. Як зауважує О. В. Нагорна, відсутність чіткої диференціації не є в цьому випадку грубою методологічною i термінологічною помилкою, оскільки в багатьох працях 3 психології правомірність чіткого розмежування відчуття як первинного сенсорного стимулу і сприймання як продукту його переробки заперечується [20, с. 18]. Про неможливість "чистого", не обробленого свідомістю відчуття пише Ч. Осгуд [21, с. 94-95]. С. Е. Поляков не виявляє істотних відмінностей між відчуттям і сприйманням і описує спільність їх походження [22, c. $10-11]$.

Дотримуючись феноменологічного трактування відчуття, сенсорна лінгвістика також не відокремлює суто чуттєвий його компонент від концептуального і не претендує на вивчення $\mathrm{i}$ опис його фізіологічного базису. У зв'язку з цим відсутність диференціації між сенсорним i перцептивним у лінгвістичному описі $є$ виправданою.

Навколишній світ ми пізнаємо за допомогою відчуттів i, говорячи про нього, користуємося словами, що передають наші відчуття. Однак далеко не всі вони рівномірно піддаються словесному вираженню. Як зауважує Н. Арутюнова, найбільш розвинуті диференційовані понятійні еквіваленти зорових вражень [2]. Будучи "головним орієнтиром людини в світі" [25, с.230], зір надає інформацію про різноманітні властивості предметів. Н. К. Рябцева перераховує фізичні явища, які охоплює ситуація зорового сприймання, і наводить приклади відповідної лексики зорових відчуттів російської мови: світло, колір, забарвлення (яркий, бельий, блестеть); розміри і форма (длинный, большой, квадратный); кількість (мало, много); фізичні властивості (тяжельй, сильньй); простір і розташування (здесь, там, внутри); 
відстань, напрямок, перспектива (далеко, близко, вверх, направо); місцезнаходження спостерігача й орієнтація (до, перед, сзади); сліди і відбитки (метка, знак); геометричні фігури (линия, угол, кривая); стан середовища, через яке сприймається предмет (туман, пелена, завеса); наявність перешкод (загораживать, прикрывать); сила і стан зорової здатності (близорукий, дальнозоркий); специфічні “візуальні” операції (искать, найти, следовать, заметить, обнаружить); “одиниці”" спостереження (вид, обзор, панорама, зрелище); ідентифікація, порівняння і розрізнення самих фізичних предметів, процесів і явищ (появиться, расти, исчезнуть) [25, с. 232].

Значення, що відображають слухові й особливо смакові, нюхові й дотикові враження, більшою мірою дифузні, внутрішньо недискретні [2]. В. К. Харченко, розглядаючи в російській мові “відкриті ряди провідних номінацій слуху”, організованих за частиномовним принципом, виокремлює іменники (слух, звучание, голос, шелест та ін.; найменування музичних інструментів, що символізують їхнє звучання: скрипка, виолончель, свирель, арфа та ін.); прикметники (на позначення сили звуку, наприклад: громкий, тихий, звучный; на позначення мелодики, наприклад: протяжный, вибрирующий; на позначення тембру голосу, наприклад: клокочущий, писклявый); дієслова (сльшиать, слушать, звучать, иуршать та ін.); прислівники (громко, тихо, бесшумно та ін.); вигуки і звуконаслідувальні слова (Чу!, ку-ка-ре-ку та ін.) і фразеологізми (кричать во всю Ивановскую; уши вянут; подавать голос; предать гласности та ін.) [14, с. 33]. На рівні вербальної реалізації, більшість атрибутів звуку не $\epsilon$ еталонними, хоча на рівні психіки майже всі звуки сприймаються як еталонні, що свідчить про двоїсту природу звуку: акустичну й психічну. Почувши певний натуральний звук, ми намагаємося знайти для нього певний аналог серед знайомих звуків - визначити його референт, порівнюючи з певним набором еталонів. Сьогодні існує якісно нове акустичне середовище людини, що продукує “штучні звуки”, для яких специфічною особливістю є відсутність натуральних аналогів [27, с. 183].

Лексика смакового й нюхового сприймання кількісно досить обмежена [1, с. 10]. Щодо одоративних відчуттів, то немає єдиної класифікації запахів, відсутні типові нюхові еталони, що знаходить своє відображення в мові. Найменування для типів запахів оцінюються за афективно зарядженою шкалою від “приємного" до "неприємного" (fragrance, aroma, smell, odor, stench тощо) [20, с. 49]. В. К. Харченко до номінацій запаху в російській мові відносить іменники (запах, аромат, вонь, амбре та ін.); прикметники (на позначення позитивного запаху, наприклад: душистый, пахучий, благоуханныци, ароматныцй; на позначення негативного запаху, наприклад: тяжёльий, смрадный, кисльй; на позначення ступеня вираженості запаху, наприклад: лёгкий, резкий); дієслова (пахнет, разит, веет, тянет, воняет, несёт та ін.); прислівники (душисто, ароматно, легко та ін.) і фразеологізми (тыкать носом; дурно пахнет та ін.) [14, с. 42]. Хоча одоративний модус обслуговується окремими лексемами, точно виразити запах мовними засобами майже неможливо [27, с. 204]. “Бідність” запахової лексики компенсується багатством асоціативних та узагальнених образів, за якими відкривається специфічний для певної лінгвокультури “асоціативний профіль" образів свідомості, що інтегрують притаманний певному етносу чуттєвий досвід, домінантні цінності та орієнтири, зокрема національно-етнічні стереотипи $[29$, с. 73$]$.

Смак, нарівні з дотиком і нюхом, традиційно відносять до “нижчих відчуттів”. Одна 3 основних причин такого низького рангу смаку в ієрархії сенсибілій полягає в його безпосередньому зв'язку з втамуванням голоду і спраги - базових фізіологічних потреб людини. Смак виникає лише в умовах безпосереднього контакту з предметом сприймання і не надає перцептору можливості дистанціюватися від нього. В англійській мові існує слово taste "смак” і слово flavour, яке позначає більш комплексне поняття, що охоплює власне смакові та нюхові відчуття, які виникають під час дегустації їжі [20, с. 51]. В. К. Харченко до лексики смаку в російській мові зараховує такі іменники, як, наприклад, вкус, привкус, сладость, пряность, острота; прикметники (горький, кисльй, солёньй, терпкий та ін.); дієслова (вкусить, попробовать, посахарить та ін.); прислівники (кисло, безвкусно, аппетитно та ін.); фразеологізми (соль земли; за семь верст киселя хлебать; хлеб да соль та ін.) [14, с. 47].

Думка про “надійність” дотику як інструмента пізнання реальності висловлювалася ще Е. Б. де Кондільяком, який вважав, що тільки за допомогою тактильних відчуттів ми можемо 
точно оцінити об’єкти навколишнього світу, і тільки тактильні відчуття надають нам інформацію, що є істинною для всіх [15, с. 237-333] Як слушно спостеріг М. Н. Епштейн, можна здійснити зорове або слухове “насильство” над об'єктом у вигляді підглядання або підслуховування, тобто “невідомого для нього спостереження”. Однак неможливо здійснити тактильне “насильство”, оскільки торкатися чогось можна лише у відповідь на такий самий дотик [7, с. 25].

Дотик може бути активний i пасивний. Активний дотик здійснюється під час цілеспрямованого руху руки по поверхні предмета. Зауважимо, що деякі дослідники розуміють “тактильний” як той, що сприймається лише пальцями руки, а не всією шкірою [20, с. 43]. Торкаючись предмета, обмацуючи його, перцептор отримує уявлення про його форму, властивості поверхні, температуру, пружність тощо. Важливо врахувати при цьому, що рецептори, які забезпечують тактильне сприймання, розташовані по всьому тілу, і в цьому сенсі вся поверхня людської шкіри є інструментом тактильної взаємодії зі світом, проте для активного дотику використовуються переважно рука, язик і ступня. Пасивний дотик - це сприймання об'єкта, що впливає на руку, яка перебуває в спокої. При пасивному дотику суб'єкт фактично виступає об'єктом зовнішнього впливу. Аналіз фактів мови показує, що це протиставлення зафіксоване в мові. Наприклад, англійське дієслово feel, яке може означати як “відчувати”, так i "обмацувати", використовують у формах Continuous лише в ситуаціях активного дотику (She is feeling the velvet - Вона шупає оксамит, але The velvet feels soft-Oксамит м'який на дотик). В. К. Харченко, аналізуючи лексику дотику в російській мові, наводить приклади іменників (осязание, прикосновение, объятие, тепло); прикметників (на позначення температури: жаркий, прохладный, холодный; на позначення густини: твёрдый, мягкий, плотный; на позначення властивості поверхні: гладкий, скользящий, шершавый; на позначення в'язкості: вязкий, тягучий); дієслів (трогать, щупать, касаться); прислівників (горячо, холодно, жсидко) і фразеологізмів (не клади пальца в рот; попадаться в руки; висеть на шее; наступать на пятки) [14, с. 40].

Висновки. У статті проаналізовано низку базових понять нової лінгвістичної дисципліни - сенсорної лінгвістики, які репрезентують поняттєву картину цього розділу мовознавства, що вивчає мову перцепції, вербалізацію показників п’яти органів чуття: зору, слуху, нюху, смаку і дотику.

\section{References}

1. Apresian, Yuriy. 1995. Izbrannyye trudy. T. 1: Leksicheskaya semantika: Sinonimicheskiye sredstva yazyka. Moskva: Yazyki russkoy kultury.

2. Arutiunova, Nina. 1999. Yazyk i mir cheloveka. Moskva: Yazyki russkoy kultury.

3. Bakhtin, Nikolai. 1995. Iz zhyzni idey: Statyi, esse, dialogi. Moskva: Labirint.

4. Bulyubash, Anzhela. 2016. "Pertseptivnyi modus "zapakh" i sredstva ego yazykovogo oznachivaniya v poeticheskoy rechi I. A. Bunina i N. A. Zabolotskogo". Mezhdunarodnyy nauchno-issledovatelskiy zhurnal. Ekaterinburg: Poligrafist 8(50), 5: 90-93. doi.10.18454/IRJ.2016.50.218.

5. Bryleva, Roza. 2016. "Funktsionalno-semanticheskoe issledovaniye olfaktornoi leksiki v russkom, frantsuzskom i bashkirskom yazykakh". PhD diss., Ufa.

6. Drobnick, Jim. 2006. "Introduction: Olfactocentrism". The Smell Culture Reader. Oxford, New York: Berg Publishers 1-9.

7. Epshteyn, Mikhail. 2006. "Khaptika: Chelovek osyazayushchiy”. Telo svobody. Sankt-Peterburg: Aleteyya16-38.

8. Frolova, Olga. 2006. "Pertseptivnyi modus v zhestko strukturirovannom tekste". Philological Studies 4(1). https://journals.ukim.mk/index.php/philologicalstudies/article/view/814/736

9. Hoffmann, Viktoria von. 2016. From gluttony to Enlightenment: The world of taste in Early Modern Europe. Chicago: University of Illinois Press.

10. Holley, Andre. 2002. "Cognitive aspects of olfaction in perfumer practice". Olfaction, Taste, and Cognition. Cambridge: Cambridge University Press 16-26.

11. Howes, David. 2003. Sensual relations: Engaging the senses in culture and social theory. Ann Arbor, MI: University of Michigan Press.

12. Howes, David, and Classen, Constance. 2014. Ways of sensing: Understanding the senses in society. New York: Routledge.

13. Johnson, Bruce. 2017. "Sound studies today: Where are we going?" A Cultural History of Sound, Memory, and the Senses. New York: Routledge 7-22.

14. Kharchenko, Vera. 2012. Lingvosensorika: Fundamentalnyye i prikladnyye aspekty. Moskva: Knizhnyy dom "Librokom". 
15. Kondilyak, Etyenn Bonno. 1982. "Traktat ob oshchushcheniyakh". Sobraniye sochineniy: v 3-kh t. Moskva: Mys1 2: 189-399.

16. Kostyayev, Aleksandr. 2007. Vkusovyye metafory i obrazy v kulture. Moskva: Izdatelstvo LKI.

17. Luriya, Aleksandr. 2006. Lektsii po obshchey psikhologii. Sankt-Peterburg: Piter.

18. Majid, Asifa, and Levinson, Stephen C. 2011. "The senses in language and culture". Senses and Society 6(1): 5-18.

19. Nagornaya, Aleksandra. 2014. Diskurs nevyrazimogo: Verbalika vnutritelesnykh oshchushcheniy. Moskwa: LENAND.

20. Nagornaya, Aleksandra. 2017. Lingvosensorika kak perspektivnoye napravleniye sovremennykh lingvisticheskikh issledovaniy. Moskva: INION RAN.

21. Osgud, Charlz. 2009. "Znacheniye termina 'vospriyatiye'". Psikhologiya oshchushcheniy $i$ vospriyatiya. Moskva: AST: Astrel 94-96.

22. Polyakov, Sergey. 2007. Mify i realnost sovremennoi psikhologii. Moskva: Editorial URSS.

23. Psykholohichna entsyklopediya, ed. by O. M. Stepanov. 2006. Kyyiv: "Akademvydav".

24. Ruzin, Igor. 1995. "Modusy pertseptsii (zreniye, slukh, osyazaniye, obonyaniye, vkus) i ikh vyrazheniye v yazyke". PhD diss., Moskwa.

25. Ryabtseva, Nadezhda. 2005. Yazyk i estestvennyy intellekt. Moskwa: Academia.

26. Semashko, Tetyana. 2015. "Verbalna obyektyvatsiya ponyattyevoyi sfery 'pertseptyvne spryynyattya' ". Movni $i$ kontseptualni kartyny svitu 51: 465-472.

27. Semashko, Tetyana. 2016. Movni stereotypy iz sensornym komponentom v ukrayinskiy linhvokulturi. Kyiv: Art Ekonomi.

28. Smith, Mark M. 2007. Sensing the past: Seeing, hearing, smelling, tasting and touching in history. Berkeley: University of California Press.

29. Stavytska, Lesya. 2006. "Stat kriz pryzmu zapakhu”. Visnyk Lvivskoho universytetu. Seriya filolohichna. 38(II): 72-78.

30. Todes, Samuel. 2001. Body and world. Cambridge, Mass.: MIT Press Ltd.

31. Verkhoturova, Tatiana. 2009. "Lingvofilosofskaya priroda metakategorii 'nablyudatel' ". PhD diss., Irkutsk.

32. Vinogradov, Viktor. 1986. Russkiy yazyk. Grammaticheskoye ucheniye o slove. Moskwa: Vysshaya shkola.

33. Winter, Bodo. 2019. Sensory Linguistics: Language, perception and metaphor. Amsterdam; Philadelphia: John Benjamins Publishing Company. doi. 10.1075/celcr.20

Коляда Элина, Лисинская Татьяна. Базовые понятия сенсорной лингвистики. В статье рассмотрены ключевые понятия сенсорной лингвистики, изучающей систему языковых репрезентаций физиологических показателей пяти органов чувств - зрения, слуха, обоняния, вкуса и осязания. По объему воспринимаемой информации в иерархии пяти сенсорных подсистем человека первое место занимает зрение, второе - слух. Регистратором результатов восприятия являются перцептивные языковые средства, при этом лексический уровень наиболее значимый. Неравноценность перцептивных ощущений, как и разное количество языковых знаков их выражения, находит свое отражение в словарном составе языка.

Вербализаторы чувственного восприятия в языковой системе морфологически представлены разными частями речи: именами существительными, именами прилагательными, глаголами, наречиями, поскольку всем словам присуща номинативная функция. Исходя из категориального значения, в имени существительном сенсорный признак опредмечен; имя прилагательное выражает сенсорный признак как статический, неотделимый от предмета; глагол выражает динамический сенсорный признак; в наречии сенсорный признак - это признак другого (процессуального или статического) признака.

Интерес ученых к результатам языковой объективации чувственного восприятия порождает перцептивность как лингвистическую категорию. Базовым для сенсорной лингвистики является понятие “сенсорный”, используемое наравне с понятием “перцептивный”. Однако в англоязычной традиции “сенсорный” соотносится с ощущением, а "перцептивный” - с восприятием.

Для обозначения отдельного вида ощущения лингвисты используют термин “перцептивный модус". Для обозначения названий ощущений служат термины латинского происхождения: “визуальный”, “аудиальный”, “тактильный” или “гаптический”, “ольфакторный”, “густативний”.

Ключевым для работ по сенсорике является понятие “сенсорный опыт”. Самого человека, испытывающего ощущения, называют перцептором, перципиентом или экспериенцером. Термины “перцептор” и “перципиент” соотносятся с актуальным, наличным сенсорным опытом, приобретаемым “здесь и сейчас", а "экспериенцер” - с совокупным сенсорным опытом, аккумулируемым на протяжении жизни человека.

Ключевые слова: сенсорная лингвистика, перцептивность, перцептивный модус, сенсорная лексика, часть речи.

Koliada Elina, Lisinska Tetiana. Basic Notions of Sensory Linguistics. The article considers the key notions of sensory linguistics, which deals with the system of linguistic representations of physiological indicators of the five senses sight, hearing, smell, taste, and touch. Sensory linguistics is the study of how language relates to the senses. Sensory perception is the reflection of certain properties of objects during their immediate action on a sense organ. According to the amount of perceived information, vision ranks first and hearing ranks in second place, followed by the subordinate senses of smell, taste and touch. Perceptual language describes physical feelings using words based on the five senses, with the lexical 
level being the most significant. The inequality of perceptual sensations, as well as the different number of linguistic signs of their expression, is reflected in the vocabulary of the language. Linguists suggest that there is more lexical differentiation for visual concepts than for the other senses.

Sensory words belong to different parts of speech: nouns, adjectives, verbs, and adverbs, since all words perform a nominative function. Perceptual features expressed by nouns are objectified; adjectives express perceptual features that do not evolve in time and are inseparable from objects; verbs express dynamic perceptual features, and adverbs express perceptual features as secondary qualities, i.e. qualities of another (dynamic or static) quality.

Perceptuality can be regarded as a linguistic category. In sensory linguistics, the basic notion is "sensory", which is used along with the notion "perceptual". However, in the English tradition, the notion "sensory" is associated with sensation, and the notion "perceptual" - with perception. Linguists use the term "perceptual mode" to refer to a particular type of sensation. The terms denoting perceptual modalities are of Latin origin: "visual", "audible", "tactile" ("haptic"), "olfactory", and "gustatory".

Other frequently used terms are "sensory experience", "percipient", and "experimenter". The term "percipient' presupposes the actual, available sensory experience gained "here and now", and the term "experimenter" - the total sensory experience accumulated during a person's life.

Key words: sensory linguistics, perceptuality, perceptual mode, sensory vocabulary, part of speech.

DOI: https://doi.org/10.32782/2410-0927-2020-12-20

УДК 811.111(73)’42Тарантіно:791.222.43

Малімон Леся, Барило Яна

\section{ЛІНГВОКОГНІТИВНІ ОСОБЛИВОСТІ КІНОДИСКУРСУ ТВОРІВ КВЕНТІНА ТАРАНТІНО (НА МАТЕРІАЛІ ФІЛЬМУ “БЕЗСЛАВНІ ВИРОДКИ")}

Стаття присвячена аналізу особливостей кінодискурсу творів режисера Квентіна Тарантіно на матеріалі фільму “Безславні виродки”. Поняття “кінодискурс" розглядається як комплексне, що включає в себе велику кількість аспектів та складових, а саме вербальних, невербальних та екстралінгвальних. У статті досліджено специфічні риси кінодискурсу цього фільму як окремо взяті, так і ті, що формують неповторний режисерський стиль та повторюються в багатьох фільмах Тарантіно. На думку авторів, аналіз кінодискурсу та сам факт виділення його серед інших видів дискурсу є ключовим для розуміння багатьох факторів комунікації, оскільки кіно як мистецтво є засобом відтворення реальності та соціального пізнання. Останні ж, зі свого боку, піддаються впливу кінодискурсу. У статті доведено, що головними та яскраво вираженими рисами кінодискурсу цього фільму є інтертекстуальність, цілісність, широке використання підтексту та створення ефекту саспенсу, при чому більшість із цих ознак $\epsilon$ взаємопов'язаними та виступають як результат впливу окремих мовних явищ. Ці характерні риси виступають як засоби передачі інформації (вербальної, невербальної або ж екстралінгвальної), допомагають правильно інтерпретувати внутрішні почуття мовців у певній ситуації та зрозуміти їхнє бачення цих ситуацій, сприйняття інших мовців чи об'єкта дискусії. Автори наголошують, що всі раніше згадані риси, а саме: використання багатьох мов, перемикання мовних кодів, застовування вербальних маніпуляцій, велика кількість сюжетних ліній, які зрештою мають об'єднатись в одне, формують структуру, стиль та розуміння кінокартини. Кінотекст є важливою складовою в синтетичній структурі кіно, поруч із такими значущими для смислової та естетичної завершеності екстралінгвальними складовими, як візуальний ряд, звукова інформація, візуальні та механічні спеціальні ефекти, комп'ютерна графіка та ін. Стаття звертає увагу на важливість аналізу кінодискурсу у світлі збільшення впливу, i, як наслідок, популярності й релевантності мистецтва кіно, яке на сьогодні є не лише розвагою чи частиною масової культури, але й засобом впливу на комунікацію та соціальне пізнання; а окремі фільми є важливою складовою світового кіноресурсу та кінодискурсу.

Ключові слова: кінодискурс, підтекст, саспенс, інтертекстуальність, мовний код.

Вступ Кінематограф є одним з наймолодших та, безсумнівно, найпоширеніших видів мистецтва, що набуває дедалі більшого визнання у світі як перспективний предмет дослідження. В епоху візуалізації інформації суто вербальні тексти відходять на другий план, поступаючись місцем медіатексту. Саме кіно стає визнаним засобом відображення реальності, соціального пізнання та водночас розвагою.

Яскравою характерною рисою життя сучасної людини є мультитаскінг, тобто виконання та сприйняття кількох дій чи розумових операцій одночасно. Кіно створюється за подібним принципом: це поєднання візуальної інформації, медіатексту, звукової інформації та технологій.

(С) Малімон Л., Барило Я., 2020 